\title{
DETERMINATION OF DECIMAL REDUCTION TIME (D-VALUE) OF CHEMICAL AGENTS USED IN HOSPITAL DISINFECTION
}

\author{
Priscila Gava Mazzola*; Alzira Maria da Silva Martins; Thereza Christina Vessoni Penna \\ Departamento de Tecnologia Bioquímico Farmacêutica, Universidade de São Paulo, São Paulo, Brasil.
}

This paper corresponds to an "extended abstract" selected for oral presentation in the $22^{\text {nd }}$ Brazilian Congress of Microbiology, held in Florianópolis, SC, Brazil, in November 17-20, 2003

\begin{abstract}
Prior to selecting disinfectant for low, intermediate and high (sterilizing) levels, the decimal reduction time, Dvalue, for the most common or persistent bacteria identified on a medical device or at a health care facility should be determined. The $\mathrm{D}$-value was determined by inoculating $100 \mathrm{~mL}$ of disinfecting solution with $1 \mathrm{~mL}$ of a bacterial suspension. At regular intervals, $1 \mathrm{~mL}$ aliquots of this mixture were transferred to $8 \mathrm{~mL}$ of growth media containing a neutralizing agent, and incubated at optimal conditions for the microorganism. $B$. stearothermophilus and E. coli were the most resistant bacteria for the disinfecting and sterilizing procedures.
\end{abstract}

Key words: decimal reduction time, sanitizers, desinfection.

\section{INTRODUCTION}

To evaluate the efficacy of the chemical agents for hospital use against the bacteria ( $S$. aureus, E. coli, E. cloacae, $S$. marcescens and A. calcoaceticus) involved in the outbreaks of infections in hospital nurseries in Brazil, the resistance of these bacteria to the particular disinfectant was investigated and expressed in decimal reduction time (D-value). The confidence levels were set for 6 to $12 \log _{10}$ reduction of the initial population of bacterium in order to a predicted probability of a surviving microorganism of $10^{-1}$ or better (1).

\section{MATERIALS AND METHODS}

The bacterial strains, obtained from lyophilized culture collection at the Adolfo Lutz Institute (IAL, SP, Brazil), were $E$. cloacae; S. marcescens; and A. calcoaceticus. The reference bacteria used were E. coli, $S$. aureus, B. subtilis, and $B$. stearothermophilus.

The chemical agents were: chlorhexidine digluconate, sodium dichloroisocyanurate, glutaraldehyde, formaldehyde, a mixture of peracetic acid (and hydrogen peroxide plus acetic acid (Minncare ${ }^{\circledR}$ ) were used $(1,2,3)$.

The agents used to inactivate the test disinfectants in solutions at $1 \%$ concentration, were: polysorbate 80 (chlorhexidine), glycine (glutaraldehyde and formaldehyde), catalase (Minncare $\left.{ }^{\circledR}\right)$; sodium thiosulphate (sodium dichloroisocyanurate) $(1,3,4)$.

Decimal reduction time (D-value) is the interval of time required, under a defined set of conditions, to provide a one decimal logarithm $\left(1-\log _{10}\right)$ or $90 \%$ reduction in the initial viable bacterial population (bioburden). The determination of the $\mathrm{D}$-value for the test disinfectant consisted in the transference of $1.0 \mathrm{~mL}$ of a $24 \mathrm{~h}$ suspension of the test bacterial strain into $100 \mathrm{~mL}$ of the disinfectant solution that is kept in constant agitation at a controlled temperature room $\left(\right.$ at $\left.25^{\circ} \mathrm{C} \pm 1.0^{\circ} \mathrm{C}\right)$, at time zero. At regular intervals a sample of the $1.0 \mathrm{~mL}$ mixture was transferred to $8 \mathrm{~mL}$ of TSB containing $1 \mathrm{~mL}$ of a inactivating agent at $1 \%$ concentration to guarantee a complete inactivation of the disinfectant without interfering with survivor growth. Using TSA pour plates, the survivors were evaluated (1).

*Corresponding author. Mailing address: Departamento de Tecnologia Bioquímico Farmacêutica, Faculdade de Ciências Farmacêuticas, Universidade de São Paulo, Av. Prof. Lineu Prestes, 580, Bl. 16. 05508-900, São Paulo, SP, Brasil. Fax: (+5511) 3091-3694. E-mail: pmazzola@usp.br 


\section{RESULTS}

The vegetative strains which showed the best resistance to the solution of $0.4 \%$ chlorhexidine were $E$. cloacae $(\mathrm{D}=8.3 \mathrm{~min})$ and S.aureus $(\mathrm{D}=5.9 \mathrm{~min})$; the more sensitive ones were $A$. calcoaceticus $(\mathrm{D}=4.1 \mathrm{~min})$, S. marcescens $(\mathrm{D}=4.0 \mathrm{~min})$ and E.coli $(\mathrm{D}=3.0 \mathrm{~min}$ ). A time interval of 3 to 4 minutes was enough to reduce $90 \%$ of the population of $E$. coli, S. marcescens and $A$. calcoaceticus; a $3 \log _{10}$ reduction in bioburden for these species varied between 9 to 12 minutes. The spore strains exposed to $2 \%$ chlorhexidine showed close $\mathrm{D}$-values among themselves $\mathrm{D}=9.1$ $\min$ for $B$. stearothermophilus and $\mathrm{D}=6.7 \mathrm{~min}$ for $B$. subtilis.

In a solution of $5000 \mathrm{mg} / \mathrm{L}(0.5 \%)$ of formaldehyde, the spore formers B. stearothermophilus and B. subtilis exhibited similar D-values of $10.9 \mathrm{~min}$ and $11.8 \mathrm{~min}$, respectively, showing twice the resistance of $A$. calcoaceticus $(\mathrm{D}=5.2 \mathrm{~min})$ and $E$. cloacae $(\mathrm{D}=4.5 \mathrm{~min}$ ); and five-fold resistance as determined for $S$. marcescens $(\mathrm{D}=2.1 \mathrm{~min})$, the most sensitive species. Both $B$. subtilis and $B$. stearothermophilus have proven to be adequate BIs in the evaluation of the efficacy of formaldehyde in the immersion of medical devices. Periods from $65.3 \mathrm{~min}$ to $141.3 \mathrm{~min}$ are needed to reduce 6 and $12 \log _{10}$ of the initial spore population.

In a solution of $2 \%$ glutaraldehyde, the spore formers $B$. subtilis and B. stearothermophilus both exhibit the same Dvalue, $\mathrm{D}=25.0 \mathrm{~min}$, which is approximately 3 to 4 times greater than that determined for the most resistant vegetative species of $E$. coli $(\mathrm{D}=7.1 \mathrm{~min})$ and $E$. cloacae $(\mathrm{D}=6.7 \mathrm{~min})$. The more sensitive vegetative strains were $A$. calcoaceticus $(\mathrm{D}=4.7 \mathrm{~min})$, S. marcescens $(\mathrm{D}=5.0$ minutes), $S$. aureus $(\mathrm{D}=5.9$ minutes $)$ and E. cloacae $(\mathrm{D}=6.7$ minutes). B. subtilis and B. stearothermophilus proved to be BIs appropriate for the evaluation of glutaraldehyde as a sterilizing agent, requiring exposure times of $300 \mathrm{~min}(5 \mathrm{~h})$, to undergo a $12 \log _{10}$ reduction in viable sporeforms. Glutaraldehyde is also appropriate in the disinfection of semi-critical articles, requiring 150 min exposure for a $6 \log _{10}$ reduction, respectively, in populations of $B$. subtilis and B. stearothermophilus. Comparing the sterilizing effect of $4 \%$ formaldehyde and $2 \%$ of glutaraldehyde, the necessary time for decay $\mathrm{n}=12$ cycles of $\mathrm{B}$. subtilis varied from $92.4 \mathrm{~min}(1 \mathrm{~h}$ $32 \mathrm{~min}$ ) to $300 \mathrm{~min}$ (5h), respectively.

The bacteria the more resistant bacteria to the solution of $1 \%$ Minncare $(0.45 \%$ peracetic acid plus $2.2 \%$ of hydrogen peroxide) were $B$. stearothermophilus ( $\mathrm{D}=9.1$ minutes), E.coli $(\mathrm{D}=6.7$ minutes) and $B$. subtilis ( $\mathrm{D}=5.9$ minutes). The most sensitive strains with similar resistance were $A$. calcoaceticus $(\mathrm{D}=3.4$ minutes), E. cloacae $(\mathrm{D}=3.5 \mathrm{~min})$ and $S$. aureus $(\mathrm{D}=3.6$ minutes $)$.

The most resistant vegetative strains to a $1000 \mathrm{mg} / \mathrm{L}(0.1 \%)$ solution of NaDCC (sodium dichloroisocyanurate) were $A$. calcoaceticus $(\mathrm{D}=5.9 \mathrm{~min})$ and E.coli $(\mathrm{D}=5.9 \mathrm{~min})$. The most sensitive vegetative strains were $S$. marcescens $(\mathrm{D}=4.3 \mathrm{~min}), E$. cloacae $(\mathrm{D}=4.7 \mathrm{~min})$ and S.aureus $(\mathrm{D}=5.0 \mathrm{~min})$. E.coli was the most appropriate BI for the evaluation of $\mathrm{NaDCC}$ as a disinfectant agent ( $\mathrm{n}=6$ ycles) for an interval of $35.4 \mathrm{~min}$. To reduce a log cycle of $B$. stearothermophilus, an exposure time of $4.4 \mathrm{~min}$ to $0.2 \% \mathrm{NaDCC}$ was necessary. For B. subtilis, an exposure time of $3.8 \mathrm{~min}$ was required to provide a reduction of a logarithmic cycle. The high level disinfection parameter, $\mathrm{n}=12$, required exposure times of $53.3 \mathrm{~min}$ (B. stearothermophilus) and $26.6 \mathrm{~min}$ (B. subtilis).

\section{DISCUSSION}

A successful disinfection at low and high levels (sterilization aim) depends upon the selection of the correct chemical agent associated with a proper disinfecting procedure. A thorough understanding of the unique characteristics of each chemical agent, including their limitations and appropriate applications, is necessary. It is also essential that the chemicals used in commercial products and in the preparation of the disinfecting solutions meet established quality requirements.

\section{ACKNOWLEDGEMENTS}

FAPESP, CNPq, and Olivia Cholewa for personal communications.

\section{RESUMO}

\section{Determinação do tempo de redução decimal (valor D) dos agentes químicos empregados em desinfecção hospitalar}

Para selecionar o agente sanitizante de acordo com o nível (baixo, intermediário, alto ou esterilizante) é necessário determinar o tempo de redução decimal (valor D) para os microrganismos comumente identificados em equipamentos médico-hospitalares. $\mathrm{O}$ valor $\mathrm{D}$ é determinado inoculando-se $1 \mathrm{~mL}$ da suspensão de microrganismo em $100 \mathrm{~mL}$ da solução desinfetante. Em intervalos constantes, alíquotas de $1 \mathrm{~mL}$ da mistura devem ser transferidas para $8 \mathrm{~mL}$ de meio de cultura contendo agente neutralizante. $B$. stearothermophilus e E. coli se mostraram os microrganismos mais resistentes para soluções esterilizantes e desinfetantes.

Palavras-chave: tempo de redução decimal, sanitizantes, desinfecção.

\section{REFERENCES}

1. Penna, T.C.V.; Mazzola, P.G.; Martins, A.M. The efficacy of chemical agents in cleaning and disinfection programs. J. $B M C$ Infectious Diseases, 1:16, 2001.

2. Brazilian Ministry of Health Regulatory Agency - ANVISA - Agência Nacional de Vigilância Sanitária, http://www.saude.mt.gov.br/ vigilancia.html, 2003.

3. McDonnell, G; Russell, A.D. Antiseptics and disinfectants: activity, action, and resistance. Clin. Microbiol. Review, 12(I):147-179, 1998

4. Rutala, W.A. APIC Guideline for selection and use of disinfectants. AJIC Am. J. Infect. Control, 23:(30:35A-65A), 1995. 